\title{
IMPROVING MATHEMATICAL UNDERSTANDING AND COMMUNICATION SKILLS AND STUDENTS' LEARNING SELF- RELIANCE IN JUNIOR HIGH SCHOOL USING CONTEXTUAL APPROACH
}

\author{
Leni Farlina ${ }^{1}$, Euis Eti Rohaeti ${ }^{2}$ \\ SMP Negeri Kabupaten Cianjur \\ farlina3fn@gmail.com ${ }^{1}$, e2rht@ ikipsiliiwangi.ac.id ${ }^{2}$ \\ Received: June, 2018; Accepted: June, 2018
}

\begin{abstract}
This research is purposed to see the effect of Contextual Approach in improving not only students' understanding and communication skills, but also their self-reliance in learning mathematics. The method used in this research is quasi-experiment with non-equivalent control group design. This research has been carried out at one junior high school in Cianjur with all of its ninth classes as the population. Out of these classes, two classes are taken as the samples, namely the experimental class and the control class. The Instrument used in this research is a set of tests to evaluate the students' mathematical communication and understanding skills which has been tested beforehand. The data are obtained through the exposure of these mathematical understanding and communication skills tests. In processing the data, t-test, two-lane ANOVA, and regression have been administered. The result of the research shows that the students' mathematical understanding and communication in experiment class have improved and are better than the control class. The result has also shown that there is not any relationship between mathematical understanding skill and learning self-reliance. However, the result shows that there is a correlation between mathematic communication skill and learning self-reliance.
\end{abstract}

Keywords: Mathematical Understanding, Mathematical Communication, Students' Learning Self Reliance, Contextual Approach.

\begin{abstract}
Abstrak
Penelitian ini bertujuan untuk melihat efek dari Pendekatan Kontekstual dalam meningkatkan tak hanya kemampuan pemahaman dan komunikasi siswa, namun juga kemandirian siswa dalam mempelajari matematika. Metode yang digunakan adalah quasi-eksperimen dengan desain grup nonekuivalen. Penelitian ini telah dilaksanakan di salah satu Sekolah Menengah Pertama di Cianjur dengan seluruh kelas sembilannya sebagai populasi. Dari keseluruhan kelas Sembilan tersebut, dua kelas diambil sebagai sampel, yaitu kelas eksperimen dan kelas kontrol. Instrumen yang digunakan pada penelitian ini adalah sekumpulan tes untuk mengukur kemampuan pemahaman dan komunikasi matematika siswa yang telah diujikan terlebih dahulu. Data yang didapat adalah melalui pemberian tes kemampuan pemahaman dan komunikasi matematika siswa. Dalam memproses data, uji-t, annova dua jalur, dan regresi telah dilaksanakan. Hasilnya menunjukkan bahwa kemampuan pemahaman dan komunikasi matematika siswa di kelas eksperimen telah meningkat dan lebih baik daripada kelas kontrol. Hasil penelitian juga menunjukkan bahwa tidak ada korelasi antara kemampuan pemahaman matematika siswa dengan kemandirian belajar. Namun, hasil penelitian menunjukkan adanya korelasi antara kemampuan komunikasi matematika siswa dengan kemandirian belajar.
\end{abstract}

KataKunci: Pemahaman Matematik, Komunikasi Matematik, Kemandirian Belajar Siswa, Pendekatan Kontekstual.

How to Cite: Farlina, L., Rohaeti, E. E. (2018). Improving Mathematical Understanding and Communication Skills and Students' Learning Self-Reliance in Junior High School Using Contextual Approach. JIML, 1 (2), 92-99 


\section{INTRODUCTION}

The national education curriculum recommends mathematics as one of the subjects that must be given to the students from elementary school to high school level in order to make qualified human resources. Mathematics is very important, because almost all subjects are related to mathematics, directly or indirectly. This is in line with the essence of mathematics which states that mathematics is the quintessence of science, the source of other sciences. This means that mathematics is the basic science for other sciences, such as Physics, Chemistry, Economics, and others. Therefore, students are expected to have good mathematical understanding and communication skills. In the 2006 Curriculum (KTSP), in addition to understanding, communication is also an skill that needs to be owned and developed. Through mathematical communication, students can organize and consolidate their mathematical thinking both orally and writtenly, so that the students will be able to respond each other in the learning process. Ultimately, mathematical communication can lead students to a deep understanding of the mathematical concepts they have learned.

Collins (Asikin, 2002), in Mathematics: Applications and Connections, mentioned one of the goals to be achieved in learning mathematics. The goal is to provide the wider opportunity for students to develop and integrate communication skills orally and writtenly, modeling, speaking, writing, talking, drawing, and presenting what has been learned. The same is stated in the mathematic learning objectives formulated by the National Council of Teachers of Mathematics (2000). The difficulties in understanding mathematics, of course, will affect students' skill in communicating mathematical ideas. Ansari (2003) stated that the mathematical understanding skill is one aspect that can affect the mathematical communication skill. It is understandable as students will not be able to communicate mathematical ideas without being able to understand the mathematical idea beforehand. Therefore, it is certain that a student's communication skill will be high if his/her mathematical understanding is also high.

The lack of mathematical understanding and communication skill will be able to affect students' achievement at school. A student, who is unable to understand a mathematical idea, will be difficult to communicate the idea either orally or writtenly. The students' inskills in communicating ideas will result in students' inskills to work on problems that will have an impact on his/her achievement. This lack of mathematical communication skill can be in the form of students' inskill to interpret mathematical ideas, express mathematical ideas, and use mathematical symbols in a problem solving. This can be caused by the lack of opportunity given to the students in developing their creativities. In conventional learning models, students' creativities have likely never appeared.

Based on the observations, carried out in the ninth class at a junior high school in Cianjur, some problems in mathematics learning seem to appear. The problems are as follows: First, the average grades of mathematics of the ninth students at that junior high school have not reached the minimum criteria. Second, the learning tends to use conventional learning model which is teacher-centered and giving lots of exercise questions. Third, students tend to be passive, bored, and some of them even chat during the learning process. Continuous application of conventional learning without any innovations at all will eliminate students' creativities and activities.

In fact, creativity and activity actually influence greatly to the concept's comprehension. Active and creative students will be very easy in constructing a concept, converting an idea into a mathematical form, and communicating it. An effort to improve the skill of mathematical understanding and communication is very essential. That is why, the researcher 
94 Farlina, L., Rohaeti, E. E. Improving Mathematical Understanding and Communication Skills and Students' Learning Self-Reliance in Junior High School Using Contextual Approach

is interested to examine mathematical learning through another approach, namely Contextual Approach, and analyze its the impact to the student' mathematical understanding and communication skill and their learning self-reliance.

Contextual learning contains reflect on the knowledge gained during the learning process. The knowledge acquired by the students is stored as an enrichment or improvement of the knowledge previously possessed. To measure the achievement that has been obtained by the students, it is necessary to make an assessment. Assessment is done on all aspects, such as activity reports, homework, skills test results, presentation of findings, etc. According to Wilson (Purnamawanti, 2014) contextual learning can help teachers in relating material to real-world situations known to students. And also, it can encourage students to make connections between the knowledge that students have with their application in daily life, students are expected to be familiar to analyze, apply and link a concept.

\section{METHOD}

The method of this research is quasi-experiment where two groups are taken randomly. The first group is a group whose learning uses Contextual Approach, namely experiment group, and the second group is a group whose learning uses the conventional method, namely control group. The design of this method can be seen as follows:

\begin{tabular}{|c|c|c|}
\hline $\mathrm{O}$ & $X$ & $\mathrm{O}$ \\
\hline $\mathrm{O}$ & & $\mathrm{O}$ \\
\hline
\end{tabular}

with :

--- : not-randomly class sampling

$\mathrm{O}$ : pre-test/post-test of the mathematical understanding and communication skill and Students' learning self-reliance

X : the treatment (learning with contextual teaching approach)

The population in this research is all junior high school students in Cianjur. The sample of this research is taken from a state junior high school located in Bojongicung district. The reason for choosing this school is because it has characteristics that can represent the population, which is in accordance with the skill of mathematical understanding and communication. This school is categorized as medium-sized school with heterogeneous students' skills. The sample subject is two classes of class nine randomly selected from the existing classes. The first class is class IX-E, which is the experiment class, and the second class is class IX-D, which is the control class. The data are then processed through normality test, homogeneity test, and two average difference test, two-lane ANOVA test and linear regression test using SPSS version 21.0 for Windows software.

\section{RESULTS AND DISCUSSION}

\section{Results}

The result of the research for the mathematical understanding skill can be seen as follows:

Table 1. Data Analysis Postes and N-Gains for Achievement and Improvement of Student Mathematical Understanding Skill

\begin{tabular}{|c|c|c|c|c|c|c|c|}
\hline & & & & $\mathrm{T} \mathrm{w} \mathrm{o}$ & w a y & $\mathrm{a} \mathrm{nova}$ & Interaction \\
\hline Testing Data & $\mathrm{C} 1 \mathrm{a} \quad \mathrm{s}$ & Normality & Hom ogeneity & Method & TKAS & $\begin{array}{l}\mathrm{M} \text { e } \mathrm{th} \text { o d } \\
* \mathrm{~T} K A \mathrm{~S}\end{array}$ & Scheffe I $\mathrm{n}$ f o. \\
\hline
\end{tabular}




\begin{tabular}{|c|c|c|c|c|c|c|c|c|c|c|}
\hline \multirow{3}{*}{ PostesUnderstanding } & & & & & \multirow{3}{*}{0.000} & \multirow{3}{*}{0.891} & \multirow{3}{*}{0} & \multirow{3}{*}{\multicolumn{2}{|c|}{$\begin{array}{lll}0 & 6 & 7\end{array}$}} & \multirow{3}{*}{ No there is } \\
\hline & Experiment & 0.055 & 0 & 38 & & & & & & \\
\hline & Control & 0.502 & 0 & 38 & & & & & & \\
\hline \multirow{2}{*}{ N-Gain Understanding } & Experiment & 0.076 & 0 & $5 \quad 1$ & \multirow{2}{*}{0.170} & \multirow{2}{*}{0.867} & \multirow{2}{*}{0} & \multirow{2}{*}{\multicolumn{2}{|c|}{099}} & \multirow{2}{*}{. } \\
\hline & Control & 0.496 & 0 & $\begin{array}{lll}5 & 1 \\
\end{array}$ & & & & & & \\
\hline
\end{tabular}

Table 1 shows that the achievement of students' mathematical understanding skill in experiment class is better than the control class in terms of the students' initial skill level. The result also shows that there is an interaction between the Contextual Approach and the level of students' initial skill in generating mathematical understanding skills.

After the two-lane ANOVA test has been administered, it is proved that the most important role in achieving and improving the mathematical understanding skill is the learning method, which is, in this case, Contextual Approach. However, the initial skill levels of students' are not so instrumental in achieving and improving students' mathematical understanding skill.

Meanwhile, the result for mathematical communication skill can be seen as follows:

Table 2 Analysis of Postes and N-Gain Data for Achieving and Improving Student Mathematical Communication Skill

\begin{tabular}{|c|c|c|c|c|c|c|c|c|}
\hline \multirow[b]{2}{*}{ Testing Data } & \multirow[b]{2}{*}{$\mathrm{C} 1 \mathrm{a} \quad \mathrm{s} s$} & \multirow[b]{2}{*}{ Normality } & \multirow[b]{2}{*}{ Hom ogen eity } & T w o & w a y & $\mathrm{a} n \mathrm{o} \mathrm{a}$ & \multicolumn{2}{|c|}{ Interaction } \\
\hline & & & & Method & TKAS & $\begin{array}{l}\text { M e thod } \\
* \mathrm{~T} K \mathrm{~A} \mathrm{~S}\end{array}$ & Scheffe & $\mathrm{I} n \mathrm{f} \mathrm{o}$ \\
\hline \multirow{2}{*}{ PostesCommunication } & Experiment & 0.133 & 0.056 & \multirow{2}{*}{0.000} & \multirow{2}{*}{0.746} & \multirow{2}{*}{0} & \multirow{2}{*}{-} & \multirow{2}{*}{ No there is } \\
\hline & Control & 0.064 & 0.056 & & & & & \\
\hline \multirow{2}{*}{ N.G ain Communication } & Experiment & 0.756 & 0.373 & \multirow{2}{*}{0.000} & \multirow{2}{*}{0.864} & \multirow{2}{*}{0.892} & \multirow[b]{2}{*}{ 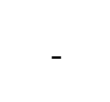 } & \multirow{2}{*}{ No there is } \\
\hline & Control & 0.119 & 0.373 & & & & & \\
\hline
\end{tabular}

Table 2 shows that the achievement and improvement of students' mathematical communication skill in experiment class is better than the control class based on the students' initial skill level. The table also shows that there is no interaction between the Contextual Approach and the level of students' initial skill in generating mathematical communication skills.

After the two-lane ANOVA test has been administered, it is proved that the most important role in the achievement and improvement of mathematical communication skills is the learning method, which is, in this case, Contextual Approach. However, the initial skill levels of students' are not so instrumental in achieving and improving students' mathematical communication skill.

For there is not any interaction between the learning method and the level of initial skill of the students' in generating their mathematical communication skills, then the Scheffe Test does not need to be carried out.

The result of the research for student self-reliance can be seen as follows:

Table 3. Data Analysis Student Self-Reliance Scale

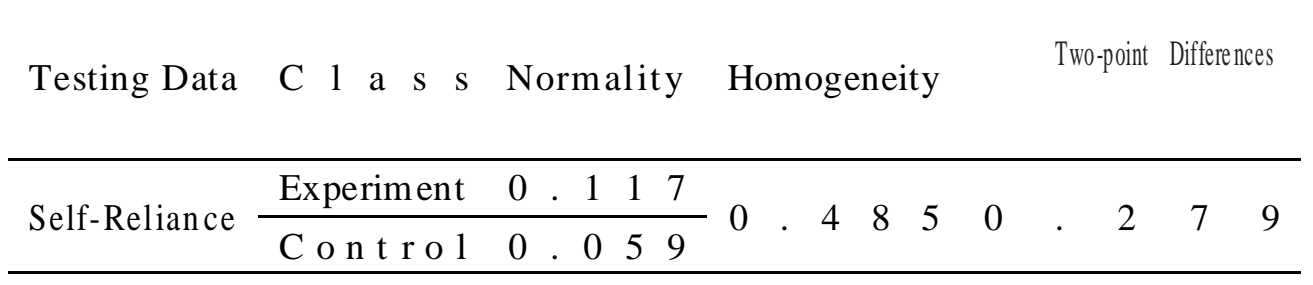


96 Farlina, L., Rohaeti, E. E. Improving Mathematical Understanding and Communication Skills and Students' Learning Self-Reliance in Junior High School Using Contextual Approach

Table 3 shows that the students' learning self-reliance in experiment class are not so different from the control class in terms of initial skill level. The result also shows that there is no relationship between the skill of mathematical understanding and communication, mathematical understanding and learning self-reliance, and between mathematical communication and learning self-reliance in the classroom using Contextual Approach or using conventional approach.

The results of the research for Regression and Correlation Analysis are as follows:

Table 4. Regression and Correlation

\begin{tabular}{|c|c|c|c|c|c|c|c|}
\hline Asosiasion & 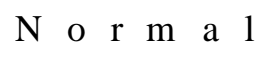 & i t $y$ & Regression & Correlation & Gu ilford & Significance & In $\mathrm{fo}$. \\
\hline \multirow{2}{*}{ Underst anding.-Communication } & Understanding & 0.055 & \multirow{2}{*}{0.382} & \multirow{2}{*}{ - } & \multirow{2}{*}{ - } & \multirow{2}{*}{-} & No there is \\
\hline & Communication & 0.133 & & & & & \\
\hline \multirow{2}{*}{ Unders standing-Sell Regulated } & Understanding & 0.055 & \multirow{2}{*}{0.992} & \multirow{2}{*}{ - } & \multirow{2}{*}{ - } & \multirow{2}{*}{ - } & No there is \\
\hline & Self Regulated & 0.117 & & & & & \\
\hline \multirow{2}{*}{ Communication - Seff Regulatad } & Communication & 0.133 & \multirow{2}{*}{0} & \multirow{2}{*}{0.002} & \multirow{2}{*}{ Kecil } & \multirow{2}{*}{$\begin{array}{lllll}0, & 0 & 0 & 2\end{array}$} & Tthere is \\
\hline & Self Regulated & 0.117 & & & & & \\
\hline
\end{tabular}

\section{Discussion}

From the results the of data processing, it is found that contextual learning affects the students' mathematical understanding skill. In terms of mathematical understanding skill achievement based on learning method, it is seen that the contextual learning actually helps students achieve mathematical understanding skill. Meanwhile, if we are to see based on TKAS, it is seen that there is no significant difference between students' mathematical understanding skills on certain TKAS. In terms of mathematical understanding skill improvement based on learning method, it is seen that the contextual learning does not help students improve mathematical understanding skill. Meanwhile, if we are to see based on TKAS that there is no significant difference between students' mathematical reasoning skills on certain TKAS.

The results of data processing also show that contextual learning affects the students' mathematical communication skills. In terms of mathematical connection skill improvement based on learning method, it is seen that the contextual learning actually helps students improve mathematical connection skills. Meanwhile, if we are to see based on TKAS that there is no significant difference between students' mathematical communication skills on certain TKAS.

The results of data processing also reveal that contextual learning does not affect students' learning self-reliance. In terms of mathematical learning self-reliance based on learning method, it is seen that the contextual learning does not help students develop their learning self-reliance. Meanwhile, if we are to see based on TKAS that there is a significant difference between students' learning self-reliance in certain TKAS.

From the results of the data processing, it is found that there is no correlation between the mathematical understanding skill and mathematical communication skills, there is no correlation between the skill of mathematical understanding with learning self-reliance, and there is a correlation between communication skills with learning self-reliance. From the results of data processing, it can also be seen that there is an interaction between contextual 
learning approach and the students' mathematical understanding skill either on high, medium or low level of TKAS. Meanwhile, from the data processing, it can be seen that there is no interaction between contextual teaching approach and students' mathematical communication skills either on high, medium, or low level of TKAS.

Moreover, the results of data processing also show that there is no interaction between contextual learning approach with student learning self-reliance either on high, medium, or low level of TKAS. Contextual learning is started by constructivism stage that develops students' thinking towards meaningful learning by working alone, finding problems by themselves, and constructing their own new knowledge or skills. At this stage, students are directed to be examples-observer and observing from everyday life. At the constructivism stage, students find it difficult to build their own knowledge. This is because the students are accustomed to receiving material directly from the teacher. Teachers can make it easy for this process by giving opportunities for students to find or apply their own ideas and teach students to become aware and consciously use their own strategies for learning. Teachers can provide students the steps that take students to a higher level of understanding with their own notes that they write in their own language and words. At the stage of learning community of constructivism, students try to find the problems themselves in the students' working sheets. The knowledge and skills acquired by the students are expected not only to recall a set of facts, but more than that, their knowledge and skills must be the result of their own finding. At this stage the teacher acts as a facilitator and motivator for students in inquiring activities. The material found directly by the students through direct experience and inquiry will be more durable in the cognitive structure of the students' because the knowledge is built by the students themselves little by little with direct experience.

However, similar to the constructivism stage, at the inquiry stage students also find it difficult to find the concept because so far they are accustomed to be given direct explanation by the teacher. One solution is to provide direct assistance in the students' working sheets using some guidances on the working sheets. Students fill in some empty sections and finally find the concept. Questioning stage is where the students ask the teacher or their friends. At this stage, the teacher can also ask the students. Knowledge improvement is always started by asking. For the teacher, questioning stage is viewed as activities of encouraging, guiding and assessing students' thinking skills. For students, questioning stage is an important part in doing information inquiry, informing what has already been known and leading to aspects that have not been known. Furthermore, questioning stage does not only encourage the students to convey ideas or opinions, but also train the skill to answer questions correctly. However, students are still embarrassed to ask questions and express opinions. One of the solutions is the teacher may praise the student who want to ask or answer questions so that it can motivate students to want to ask and answer questions. Community learning stage is where students learn how to group, discuss, and exchange information with fellow members of the group. Teachers should organize the material in a way that students are able to discover and develop the material through community learning and learning experiences in an atmosphere of cooperation.

In cooperative groups, students may share each other and become peer tutors. Through peer tutors, student smay receive more information openly due to the absence of age gap. The difficulty that may appear at this stage is that some students may be actively working on the working sheets, while others seem to be unconcerned and not get involved in the group learning. The solution proposed needs to provide an assessment of the cohesiveness of students in the group to make students more solid. The next step is the modeling stage where the process is focusing on the attention, motivation, delivery of competence, goals, directions, 
98 Farlina, L., Rohaeti, E. E. Improving Mathematical Understanding and Communication Skills and Students' Learning Self-Reliance in Junior High School Using Contextual Approach

signs and examples. In learning certain skills and knowledges, there are models that can be imitated. Teachers can be models. For example, the teacher can give a way to do something with the condition that the students must find the concept themselves. But the teacher is not the only model means. The model can involve students. For example, students are appointed to give an example to their friends. At this stage, students present the results of their discussion in front of the class. This exercise encourages the students to speak in front of the class.

There is also a stage of questioning at this point when there are friends from other groups ask or refute the group that is doing presentation. The difficulty at this stage is that most students are embarrassed when asked to do presentation or to be model. The solution that may be practiced is that the students should be given the motivation to be a model in front of the class. The reflection stage is done at the end of the lesson. Reflection is an attempt to re-look, reorganize, re-analyze, re-clarify and reevaluate what has been learned. Teachers, together with the students, reflect the material that has been learned. At this stage, there is no significant difficulty, because students are guided by teachers to conclude. Overall, the students in the experimental class have the skills to understand mathematics better than those in the control class. However, their skills of communicating are still lacking, let alone control class which is still very lacking in the skill of mathematical communication. From the calculation, we may find that in term of average pre-test score of mathematical understanding skill, the experimental class has the higher results than the control class.

Additionally, the average post-test score of the mathematical understanding skill of the experimental class is also higher than the control class. And the average pre-test and post-test score of mathematical communication skill, the experimental class is higher than the control class. Overall the results of pre-test and post-test for both mathematical comprehension and mathematical communication skills are still in the level of moderate to high.

\section{CONCLUSION}

Based on the data analysis and discussion, some things may be concluded as follows: Achievement and improvement of mathematical understanding skills of junior high school students of the class which uses the Contextual Approach are better than the class which uses conventional learning in terms of the mathematical initial skill. The achievement and improvement of the mathematical communication skill of the class which uses the Contextual Approach is better than the class which uses conventional learning in terms of the students' mathematical initial skill as a whole.

On the other hand, the mathematics learning self-reliance of the class which uses the Contextual Approach is better than that of the class which uses conventional learning in terms of the initial skill. Additionally, there is no correlation between the students' mathematical understanding and communication skill of experimental and control class. Moreover, there is no correlation between the skill of mathematical understanding and learning self-reliance in both classes. However, there is a correlation between mathematical communication skill and learning self-reliance in both classes. And then, there is also an interaction between the contextual learning approach and the student's initial skill level in generating mathematical understanding skills.

Furthermore, there is no interaction between the contextual learning approach and the student's initial skill level in generating mathematical communication skills. And lastly, there is an interaction between the contextual learning approach and the student's initial skill level in generating student self-reliance. 


\section{REFERENCES}

Ansari, B (2003). Menumbuhkembangkan Kemampuan Pemahaman dan Komunikasi Matematik Siswa Melalui Strategi Think-talk-write. Disertasi pada SPS UPI, Bandung: Tidak diterbitkan.

Asikin, M. (2002). Menumbuhkan Kemampuan Komunikasi Matematika melalui Pembelajaran Matematika Realistik. Mathematics Journal or Its Learning $\left(11^{\text {th }}\right.$ National Mathematics Conference Prociding).7, (Special Edition), (492-496).

Depdiknas. (2006). Kurikulum Tingkat Satuan Pendidikan (KTSP). Jakarta: Depdiknas

NCTM, (1989).Evalution Standards For School Mathematics. Available on: http//www.docstoc.com/2017/search/komunikasi-matematika.htm.

Purnamawati, Y. (2014). Meningkatkan Kemampuan Pemahaman Dan Komunikasi Matematik serta Kemandirian Belajar Siswa SMP Melalui Pendekatan Kontekstual Dengan Setting model Pembelajaran Kooperatif Tipe STAD. Thesis of the PostGraduate Program of STKIP Siliwangi Bandung: Unpublished 